\title{
The GMAP210 homologue SQL 1 modulates intraflagellar transport in C. elegans
}

\author{
S Rademakers $^{1 *}$, J Broekhuis ${ }^{1}$, M Dekkers ${ }^{2}$, J Burghoorn ${ }^{1}, \mathrm{G}$ Jansen ${ }^{1}$ \\ From First International Cilia in Development and Disease Scientific Conference (2012) \\ London, UK. 16-18 May 2012
}

The development and function of cilia require a specialised transport process, called Intraflagellar Transport (IFT). In amphid cilia of C. elegans this process uses two kinesins, kinesin II and OSM-3, which are loaded with complex A and B particle proteins and cargo molecules. We have previously shown that expression of a dominant active G-protein (GPA-3QL) in amphid channel neurons affects the coordination of OSM-3 and kinesin-II and results in shorter cilia. We performed a genetic screen to identify mutants that suppress the gpa-3QL cilia length defect and identified sql-1 (supressor of gpa-3QL), which encodes the homologue of the mammalian Golgi protein GMAP210. GMAP210 has been shown to play a role in vesicular transport from the Golgi apparatus to the cilium. SQL-1 is ubiquitously expressed in C. elegans and localizes to the Golgi. sql-1 loss of function $(l f)$ mutants show wildtype length cilia, while animals overexpressing SQL-1 have longer cilia. Speed measurements in $s q l-1(l f)$ animals showed that OSM-3 moves faster and kinesin II moves slower, suggesting that the two kinesins are partially uncoupled. Complex A and B proteins move at the same speed as OSM-3, suggesting that IFT is predominantly mediated by OSM-3 kinesin. Interestingly, in the gpa-3QL; sql-1(lf) double mutants the speed of OSM-3 is decreased. We hypothesize that SQL-1 plays a role in routing or post translational modifications of proteins that are required in the cilium for proper IFT.

\section{Author details}

${ }^{1}$ Erasmus Medical Center Rotterdam, the Netherlands. ${ }^{2}$ Biozentrum, University Basel, Switzerland.

Published: 16 November 2012

* Correspondence: j.rademakers@erasmusmc.nl

${ }^{1}$ Erasmus Medical Center Rotterdam, the Netherlands

Full list of author information is available at the end of the article
doi:10.1186/2046-2530-1-S1-P40

Cite this article as: Rademakers et al:: The GMAP210 homologue SQL 1 modulates intraflagellar transport in C. elegans. Cilia 2012 1(Suppl 1):P40.
Submit your next manuscript to BioMed Central and take full advantage of:

- Convenient online submission

- Thorough peer review

- No space constraints or color figure charges

- Immediate publication on acceptance

- Inclusion in PubMed, CAS, Scopus and Google Scholar

- Research which is freely available for redistribution

Submit your manuscript at www.biomedcentral.com/submit

\section{() Biomed Central}

C Biomed Central

C 2012 Rademakers et al; licensee BioMed Central Ltd. This is an Open Access article distributed under the terms of the Creative Commons Attribution License (http://creativecommons.org/licenses/by/2.0), which permits unrestricted use, distribution, and reproduction in any medium, provided the original work is properly cited. 